\title{
Feeding ecology of Serrapinnus notomelas (Characiformes: Cheirodontinae) in small forest streams in the Machado River basin, Rondônia, Brazil
}

\author{
Igor David da COSTA*1, Vanessa Martins da ROCHA² \\ 1 Universidade Federal de Rondônia. Departamento de Engenharia de Pesca, Rua da Paz, 4376, Bairro Lino Alves Teixeira, CEP: 76.916-000, Presidente Médici, Rondônia, Brasil. \\ 2 Universidade Federal de Santa Catarina. Rodovia Francisco Thomaz Dos Santos, 3532 - Armação do Pântano do Sul, CEP: 88066-260, Florianópolis, Santa Catarina, Brasil. \\ * Corresponding author: igordavid@unir.br
}

\section{ABSTRACT}

Studies on the trophic structure of fish give information on species autoecology and their role in the ecosystem. The aims of this study were to characterize the diet of Serrapinnus notomelas in small streams of the River Machado basin and to assess the effect of rainfall seasonality. Fish were collected bimonthly from July 2013 to May 2014 with seine nets and hand nets. The length of each specimen was measured to identify category classes. There were also measured the fullness index and volume of each ingested item, and these data were combined to obtain an alimentary index. We used ANOVA and Kruskal-Wallis to test for differences between length classes and fullness index, Chi-squared tests to detect seasonal differences in origin of food items and non-metric multidimensional scaling analysis to examine temporal variation in diet. We found that most of the specimens were longer than $20 \mathrm{~mm}$, showing a polymodal distribution. In both seasons stomachs of most fish were full. Serrapinnus notomelas feeds on items of plant and animal origin. A higher consumption of aquatic macrophytes and algae was observed, suggesting omnivorous feeding behavior with a tendency to herbivory. Items of plant and autochthonous origin were consumed more than other items in both seasons, and consumption of animal and autochthonous items varied between seasons. These results reinforce the idea that $S$. notomelas show trophic plasticity between seasons.

KEYWORDS: Characidae, Trophic ecology, Igarapés, Ornamental fish, Amazon.

\section{Ecologia alimentar de Serrapinnus notomelas (Characiformes: Cheirodontinae) em igarapés da bacia do Rio Machado, Rondônia, Brasil}

\section{RESUMO}

Estudos sobre a estrutura trófica de peixes dão informaçôes sobre autoecologia espécies e seu papel no ecossistema. Os objetivos deste estudo foram caracterizar a dieta Serrapinnus notomelas em igarapés da bacia do rio Machado e avaliar o efeito da sazonalidade das chuvas. Os peixes foram coletados bimestralmente de julho 2013 a maio de 2014, com redes de arrasto e redes de máo. $\mathrm{O}$ comprimento de cada espécime foi medido para identificar a categoria das classes. Também foram medidos o grau de repleção e o volume de cada item ingerido, e estes dados foram combinadas para se obter um índice alimentar. Foram utilizados uma ANOVA e Kruskal-Wallis para diferenças entre classes de comprimento e graus de repleção, teste de qui-quadrado para detectar diferenças sazonais na origem dos alimentos e análise de escalonamento multidimensional não-métrico para examinar variação temporal na dieta. Nós encontramos que a maioria dos indivíduos eram maiores que $20 \mathrm{~mm}$, apresentando distribuição polimodal. Para ambas as estaçôes a maioria dos estômagos apresentaram-se cheios. Serrapinnus notomelas ingeriu itens vegetais e animais. Observamos maior consumo de macrófitas aquáticas e algas, sugerindo comportamento alimentar onívoro com tendência a herbivoria. Itens de origem vegetal e autóctone foram mais consumidos que os demais itens em ambas as estaçôes, e o consumo de itens animais e itens autóctones variou entre as estaçóes. Estes resultados reforçam a ideia de que $S$. notomelas apresenta plasticidade trófica entre as estaçóes.

PALAVRAS-CHAVE: Characidae, Ecologia trófica, Igarapés, Peixe ornamental, Amazônia. 


\section{INTRODUCTION}

Understanding the trophic ecology of stream-dwelling fishes and how fishes use the spatial and seasonal components of their environment is important to support studies on community structure and investigations into biological interactions, such as predation and competition (Esteves and Aranha 1999). Trophic ecology studies show that most teleosts exhibit considerable versatility in their food habits and that their food spectrum can be influenced not only by the biology of each species but also by environmental conditions (Abelha et al. 2001).

Small forest streams (locally known as igarapés) are watercourses that are poor in nutrients and have low primary production (Mendonça et al. 2008). The food webs in these systems depend on allochthonous matter from nearby forests (Abilhoa et al. 2009). These streams are also subject to frequent, rapid flood pulses (Carvalho et al. 2013). Heavy rains in drainage basins are one factor leading to environmental changes in streams (Corrêa et al. 2012). According to Espírito-Santo et al. (2009), fish assemblages and the physical characteristics of small streams vary in the dry and rainy seasons. As the water level reaches or overtops the banks, new food resources become available to fishes (Corrêa et al. 2012). Trophic relationships in fish communities are affected by the availability of resources (Ximenes et al. 2011; Ferreira et al. 2014).

The order Characiformes is the Neotropical group of fishes with the greatest diversity of species, morphologies and behaviors (Lévêque et al. 2008). Over 1500 Characiformes species have been described to date (Reis et al. 2003). Although the subfamily Cheirodontinae is one of the best-known groups of Characidae in terms of phylogeny and taxonomy (Malabarba 2003; Bührnheim et al. 2008), there is a dearth of studies on the ecology of this subfamily (Benitez and Súarez 2009), and most of the available information is on the biological aspects of Cheirodontinae species in southern Brazil (Santi-Rampazzo et al. 2008; Benitez and Súarez 2009; Gonçalves et al. 2011).

Serrapinnus notomelas (Eigenmann, 1915) shows ornamental importance (Regulatory Directive 001/2012MPA/MMA) and contributes $0.0009 \%$ of the total ornamental fish exports of Brazilian inland waters caught in the states of Amazonas and Pará (IBAMA 2008). It is algivorous and non-migratory and does not exhibit parental care (Suzuki et al. 2004). Serrapinnus notomelas has a short life cycle and a small body size and can be found in a great variety of habitats (Luiz et al. 1998).

Seasonal variation in wind and rainfall can be expected to result in allochthonous matter entering streams in different patterns (Angermeier and Karr 1983). We hypothesize that seasonal changes will alter food resources, leading to changes in the diet, length classes, and fullness index of $S$. notomelas. The aim of this study was to characterize the diet of $S$. notomelas in small streams in the Machado River basin and to compare its composition between two different seasons (rainy and dry).

\section{MATERIALS AND METHODS}

Fish sampling was conducted in the Dom João stream (6204'51"W, $11^{\circ} 10^{\prime} 56^{\prime}$ "S), the Penha stream (6204'40"W, $\left.11^{\circ} 11^{\prime} 50^{\prime \prime} \mathrm{S}\right)$ and the Mangueira stream $\left(62^{\circ} 05^{\prime} 10^{\prime \prime} \mathrm{W}\right.$, $11^{\circ} 13^{\prime} 54^{\prime \prime}$ ), which are located in the Machado River basin in the eastern part of the state of Rondonia (Figure 1). The temperature in this region varies between $19{ }^{\circ} \mathrm{C}$ and $33^{\circ} \mathrm{C}$, and the annual precipitation is approximately $2,500 \mathrm{~mm}$ (Krusche et al. 2005). There are two well-defined seasons: the dry season (from May to October) and the rainy season (from November to April) (Fernandes and Guimarães 2002). The streams are second-order, and the sampling sites were determined according to Horton's scale, modified by Strahler (Petts 1994). Second-order streams have a sandy substratum, pastures in the adjacent matrix and a small amount of riparian vegetation, such as grass and small aquatic plants. In the dry season during the study period, the mean depth was $300 \pm$ $100.0 \mathrm{~cm}$, the mean width was $281 \pm 41.1 \mathrm{~cm}$, the mean water speed was $0.4 \pm 0.2 \mathrm{~m} \mathrm{~s}^{-1}$ and the mean flow was 33.2 $\pm 0.4 \mathrm{~m}^{3} \mathrm{~s}^{-1}$, while in the rainy season, the mean depth was $390 \pm 130.0 \mathrm{~cm}$, the mean width was $316 \pm 47.5 \mathrm{~cm}$, the mean water speed was $0.4 \pm 0.0 \mathrm{~m} \mathrm{~s}^{-1}$ and the mean flow was $49.2 \pm 0.3 \mathrm{~m}^{3} \mathrm{~s}^{-1}$.

In total, two dry and two rainy seasons were sampled: July 2013, September 2013, January 2014 and March 2014, along a $50 \mathrm{~m}$ stretch of the streams (Mendonça et al. 2005). Seine nets (picarés) measuring $2.0 \times 1.20 \mathrm{~m}$ with a mesh size of $2 \mathrm{~mm}$ and a dip net $(p u c ̧ a ́)$ with a $0.46 \times 0.33 \mathrm{~m}$ opening and a mesh size of $2 \mathrm{~mm}$ were used simultaneously along the entire stretch for one hour. Before sampling, each end of the $50 \mathrm{~m}$ sampling site was blocked with gill nets $(5 \mathrm{~mm}$ mesh size) to prevent fishes from escaping.

The fish were collected under an ICMBio (Instituto Chico Mendes de Conservação da Biodiversidade) permit (314461/2011). Every fish was euthanized using a lethal dose of clove oil (eugenol) and immediately fixed in $10 \%$ formalin solution and preserved in $70 \%$ ethanol. The species were identified following Queiroz et al. (2013), and voucher specimens were deposited in the fish collection of the Universidade Federal de Rondônia, Porto Velho, Brazil (UFRO-I 11257 e 13782).

The standard length (SL) of each specimen was measured to identify length classes (LCs). These were calculated according to the Sturges method (Sturges 1926). Stomach contents were stored in $70 \%$ alcohol, and food items were analyzed and identified to the lowest taxonomic level using Bicudo 


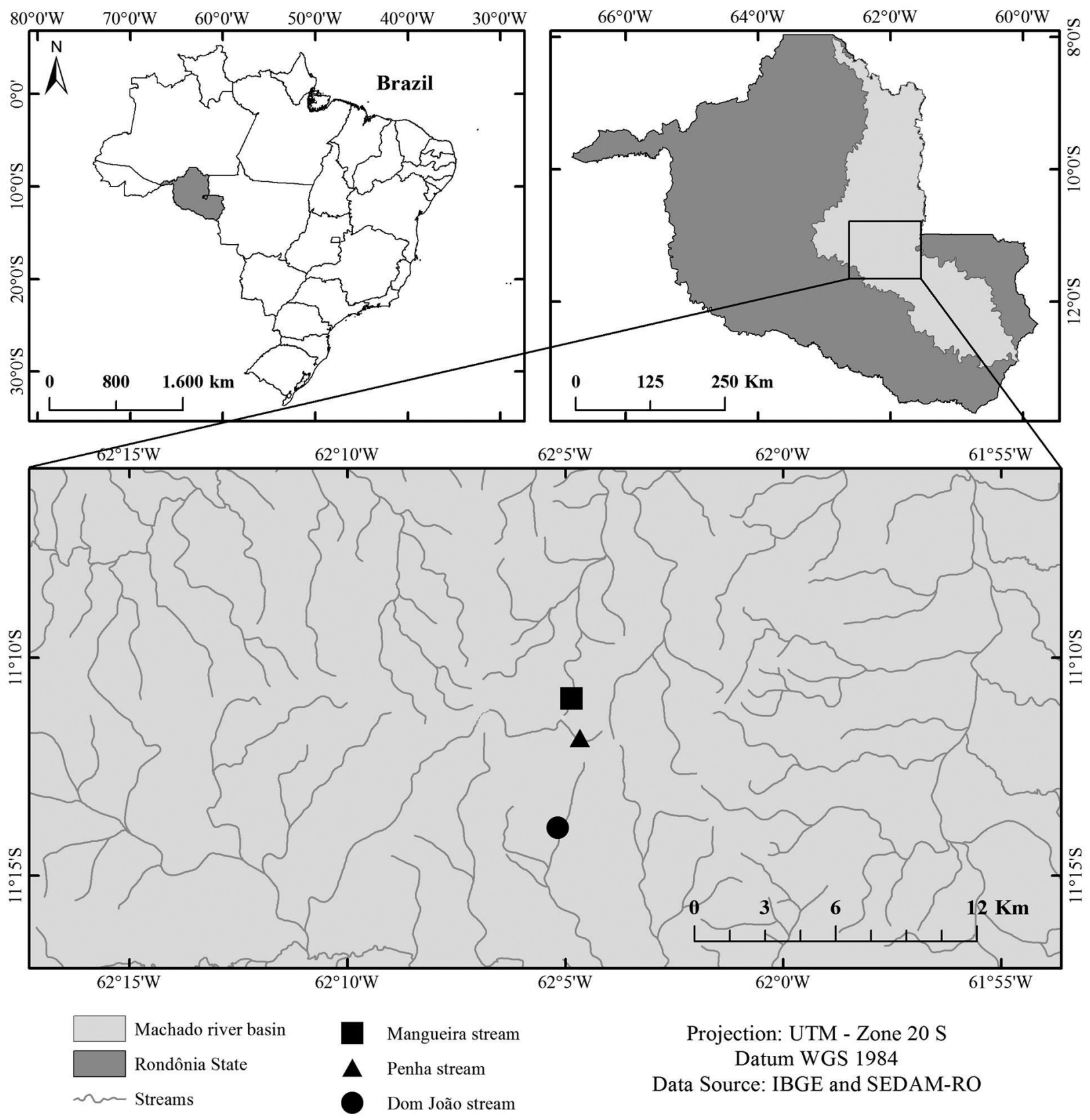

Fig. 1. Map of the Machado River basin with the study sites indicated.

and Bicudo (1970), Hamada and Ferreira-Keppler (2012) and Hamada et al. (2014) using a dissecting microscope. The occurrence frequency $(\mathrm{F} i \%)$ and the method of volumetric frequency $(\mathrm{V} i \%)$ were used to analyze stomach contents (Hyslop 1980). The occurrence frequency was calculated by recording the number of fish in which each item occurred, obtaining the percentage in relation to the total stomachs with food. For the volumetric frequency, the volume of each item was obtained by the percentage in relation to the total value of every stomach contents. The volume was obtained through gridded dish, where the volume was obtained in cubic millimeter and later transformed into milliliter (Hellawell and Abel 1971). These data were combined in an alimentary index (IA $i$ ) proposed by Kawakami and Vazzoler (1980). The index is given by the equation $\mathrm{IA} i=(\mathrm{F} i * \mathrm{~V} i) / \Sigma \mathrm{F} i * \mathrm{~V} i)^{*} 100$, 
where $i=1.2, \ldots \mathrm{n}$ food items; $\mathrm{F} i=$ frequency of occurrence of a given food item; and $\mathrm{V} i=$ volume of a given food item. Food items were grouped according to type (animal or plant) and origin (autochthonous or allochthonous). Fullness index (FI) was determined according to Hahn et al. (1999) and was coded as follows: 0 (empty), 1 (volume $<25 \%), 2$ (25\% < volume $<75 \%)$ and $3(75 \%<$ volume $<100 \%)$.

The Shapiro-Wilks test of normality and Levene's test of homoscedasticity were used to determine whether parametric ANOVA or the non-parametric Kruskal-Wallis test should be used to test for differences between LC (length classes) by season, FI (fullness index) by season and IA $i$ by season (Zar 1999). As sources of variation were considered seasons (rainy and dry), LC (12 - $14 \mathrm{~mm}, 15-17 \mathrm{~mm}, 18-20 \mathrm{~mm}$, $21-23 \mathrm{~mm}, 24-26 \mathrm{~mm}, 27-29 \mathrm{~mm}, 30-32 \mathrm{~mm}, 33-35$ $\mathrm{mm}$ and $36-38 \mathrm{~mm}$ ), (FI 0, FI 1, FI 2 and FI 3 ) and IA $i$. Chi-squared tests $\left(\chi^{2}\right)$ were applied to data that had a normal distribution and to detection of seasonal differences (rainy versus dry season) in origin of food items (Zar 1999).

Non-metric multidimensional scaling analysis (nMDS) was used to examine temporal variation in diet using the total volume of each item. The dissimilarity matrix used in the ordination was constructed using the Bray-Curtis index, with this analysis carried out using the PAST software (version 2.1.7) (Hammer et al. 2001). In nMDS analysis a low stress value (0.1), correspond to a good ordering, ensuring good reliability in the interpretation of the results (Clarke and Warwick 1994). The ANOVA and $\chi^{2}$ tests were performed were performed using the R-package ( $\mathrm{R}$ Foundation for Statistical Computing, version 3.0.1, 2013). The results were considered significant when $p \leq 0.05$.

\section{RESULTS}

A total of 372 specimens were analyzed; 228 were collected in the rainy season ( $\mathrm{SL}=12$ to $38 \mathrm{~mm}$ ) and 144 in the dry season ( $\mathrm{SL}=18$ to $38 \mathrm{~mm}$ ). Most of the specimens were longer than $20 \mathrm{~mm}$, and the $\mathrm{LC}$ with the greatest absolute frequency was LC $30-32 \mathrm{~mm}(\mathrm{n}=125 ; 34 \%)$, followed by LC $27-29$ $\mathrm{mm}(\mathrm{n}=108 ; 29 \%)$, LC $24-26 \mathrm{~mm}(\mathrm{n}=44 ; 12 \%)$ and LC $33-35 \mathrm{~mm}(\mathrm{n}=36 ; 10 \%)$. The assumptions of the ANOVA were met (Shapiro-Wilk, $p>0.05$; Levene, $p>0.05$ ). Significant differences were found between the length classes analyzed (ANOVA, $p<0.05 ; \mathrm{df}=8$ ) (Table 1 ).

A total of 219 specimens were analyzed for FI; 119 were collected in the rainy season and 100 in the dry season. The assumptions of the ANOVA were met (Shapiro-Wilk, $p>0.05$; Levene, $p>0.05)$. Significant differences were found between the fullness index analyzed (ANOVA, $p<0.05 ; \mathrm{df}=3$ ) (Table 2).

Serrapinnus notomelas ingested a wide variety of food items, including material of plant origin, such as algae
Table 1. Absolute frequency of Serrapinnus notomelas specimens at the streams in the Machado river basin, Brazil, from July 2013 to May 2014 in each length class (LC). The data shown in different letters are significant at the 0.05 level.

\begin{tabular}{lcc}
\hline \multirow{2}{*}{ LC (mm) } & \multicolumn{2}{c}{ Absolute frequency } \\
\cline { 2 - 3 } & Rainy season & Dry season \\
\hline $12-14$ & $1^{\mathrm{b}}$ & $0^{\mathrm{b}}$ \\
\hline $15-17$ & $3^{\mathrm{b}}$ & $0^{\mathrm{b}}$ \\
$18-20$ & $21^{\mathrm{a}}$ & $2^{\mathrm{b}}$ \\
\hline $21-23$ & $23^{\mathrm{a}}$ & $5^{\mathrm{b}}$ \\
\hline $24-26$ & $25^{\mathrm{a}}$ & $19^{\mathrm{a}}$ \\
$27-29$ & $56^{\mathrm{a}}$ & $52^{\mathrm{a}}$ \\
$30-32$ & $72^{\mathrm{a}}$ & $53^{\mathrm{a}}$ \\
$33-35$ & $25^{\mathrm{a}}$ & $11^{\mathrm{a}}$ \\
$36-38$ & $2^{\mathrm{b}}$ & $2^{\mathrm{b}}$ \\
\hline
\end{tabular}

Table 2. Absolute frequency of Serrapinnus notomelas specimens for each stomach fullness index class. Fullness index 0 ( $\mathrm{Fl} 0=$ empty), fullness index 1 ( FI $1=<25 \%$ ), fullness index 2 ( $F \mid 2=25 \%-75 \%$ ) and fullness index 3 (FI $3=75 \%-100 \%$ ) at the streams in the Machado River basin, Brazil, from July 2013 to May 2014. Data shown in different letters are significant at the 0.05 level.

\begin{tabular}{lcc}
\hline \multirow{2}{*}{ Fullness index } & \multicolumn{2}{c}{ Absolute frequency } \\
\cline { 2 - 3 } & Rainy season & Dry season \\
\hline Fl 0 & $0^{\mathrm{b}}$ & $0^{\mathrm{b}}$ \\
$\mathrm{Fl} 1$ & $9^{\mathrm{b}}$ & $1^{\mathrm{b}}$ \\
$\mathrm{Fl} 2$ & $30^{\mathrm{a}}$ & $15^{\mathrm{b}}$ \\
$\mathrm{Fl} 3$ & $79^{\mathrm{a}}$ & $83^{\mathrm{a}}$ \\
\hline
\end{tabular}

and macrophytes; material of animal origin, such as mites, zooplankton, scales and terrestrial and aquatic insects at different stages of the life cycle; and undefined matter (detritus/mud). The main items consumed, the fragments of aquatic macrophytes was the most important item in rainy season $(\mathrm{IA} i=54.94 ; p=0.00 ; \mathrm{df}=1)$ compared to dry season $(\mathrm{IA} i=49.01)$, as well as digested plant material (rainy, IA $i=$ 7.60; dry IA $i=5.65, p=0.01 ; \mathrm{df}=1$ ). Microsporaceae (green algae) was the most important item in dry season (rainy, IA $i=$ 5.83; $\mathrm{dry} \mathrm{IA} i=7.29 ; p=0.01 ; \mathrm{df}=1)$, as well as Desmidiaceae (rainy, $\mathrm{IA} i=0.13$; dry IA $i=6.58 ; p=0.00 ; \mathrm{df}=1)$ (Table 3).

There were significant differences between the amount of food items of allochthonous origin and the amount of food items of autochthonous origin ingested in both the dry season $\left(\chi^{2}=77.2 ; p<0.05 ; \mathrm{df}=1\right)$ and the rainy season $\left(\chi^{2}=73.6 ; p<\right.$ $0.05 ; \mathrm{df}=1)$. In both seasons consumption of autochthonous food items was greater. There was also a significant difference between the amount of material of animal origin and the 
Table 3. Percentage composition by volume (Vi), occurrence (Fi) and alimentary index (IAi) of each food item identified in the diet of Serrapinnus notomelas during the rainy and dry seasons in streams in the Machado River basin, Brazil, from July 2013 to May 2014. Allochthonous items*; autochthonous items**

\begin{tabular}{|c|c|c|c|c|c|c|}
\hline \multirow{2}{*}{ Food items } & \multicolumn{3}{|c|}{ Rainy season } & \multicolumn{3}{|c|}{ Dry season } \\
\hline & Vi\% & $\mathrm{F} i \%$ & $\mid A i$ & Vi\% & $\mathrm{Fi} \%$ & $\mathrm{IA} i$ \\
\hline \multicolumn{7}{|l|}{ Plant origin } \\
\hline Chlorophyta** & 2.44 & 3.50 & 1.73 & 4.78 & 3.53 & 3.66 \\
\hline Chaetophorales** & 0.02 & 0.09 & 0.15 & & & \\
\hline Cyanophyta** & 0.09 & 0.55 & 0.01 & 0.00 & 0.08 & 0.00 \\
\hline Sphaeropleales** & 0.00 & 0.09 & 0.12 & & & \\
\hline Amphipleuraceae** & 0.01 & 0.27 & 0.32 & 0.01 & 0.58 & 0.45 \\
\hline Bacillariaceae ${ }^{\star *}$ & 0.07 & 0.83 & 0.90 & 0.01 & 0.42 & 0.36 \\
\hline Bacillariophyceae ${ }^{\star \star}$ & 0.29 & 2.22 & 0.13 & 0.27 & 0.08 & 0.30 \\
\hline Biddulphiaceae** & 0.13 & 0.92 & 0.99 & 0.90 & 1.17 & 0.23 \\
\hline Brachysiraceae** & 0.01 & 1.30 & 1.33 & 0.00 & 0.33 & 0.00 \\
\hline Catenulaceae** & 0.04 & 1.02 & 0.01 & 0.02 & 0.67 & 0.00 \\
\hline Chlorellaceae** & 0.01 & 0.09 & 1.13 & 0.01 & 0.16 & 0.18 \\
\hline Cladophoraceae** & 0.33 & 0.65 & 0.04 & 0.30 & 0.59 & 0.03 \\
\hline Closteriaceae ${ }^{\star \star}$ & 1.05 & 4.73 & 1.03 & 1.80 & 4.46 & 1.74 \\
\hline Cymbellaceae** & 0.25 & 3.43 & 0.15 & 0.32 & 4.21 & 0.28 \\
\hline Desmidiaceae** & 0.37 & 3.71 & 0.13 & 8.89 & 6.65 & 6.58 \\
\hline Diadesmidaceae $e^{\star *}$ & 0.01 & 0.37 & 0.40 & 0.01 & 0.50 & 0.00 \\
\hline Euglenaceae** & 0.01 & 0.27 & 0.30 & 0.00 & 0.08 & 0.00 \\
\hline Eunotiaceae** & 0.15 & 1.20 & 0.03 & 0.11 & 0.59 & 0.01 \\
\hline Fragilariaceae** & 0.08 & 0.65 & 0.71 & 0.00 & 0.08 & 0.00 \\
\hline Gomphonemataceae** & 0.71 & 3.99 & 0.53 & 0.29 & 2.69 & 0.16 \\
\hline Hydrodictyaceae** & 0.01 & 0.09 & 0.12 & 0.01 & 0.50 & 0.00 \\
\hline Microcystaceae** & 0.00 & 0.09 & 0.00 & 0.02 & 0.16 & 0.00 \\
\hline Microsporaceae $e^{\star \star}$ & 10.42 & 2.69 & 5.83 & 6.90 & 4.88 & 7.29 \\
\hline Naviculaceae** & 0.14 & 1.85 & 0.03 & 0.19 & 2.61 & 0.06 \\
\hline Naviculales** & 0.26 & 2.50 & 0.13 & 0.12 & 2.27 & 0.06 \\
\hline Neidiaceae** & & & & 0.02 & 0.42 & 0.00 \\
\hline Nostocaceae** & 0.01 & 0.18 & 0.16 & & & \\
\hline Oscillatoriaceae** & 0.83 & 1.20 & 0.20 & 1.17 & 2.94 & 0.74 \\
\hline Phacaceae ${ }^{\star \star}$ & 0.01 & 0.09 & 0.11 & & & \\
\hline Pinnulariaceae** & 3.49 & 4.82 & 3.50 & 0.75 & 4.46 & 0.72 \\
\hline Pseudanabaenaceae** & 0.51 & 1.02 & 0.10 & 0.22 & 0.42 & 0.02 \\
\hline Rhopalodiaceae** & 0.01 & 0.27 & 0.30 & 0.00 & 0.08 & 0.00 \\
\hline Rivulariaceae** & 0.24 & 0.46 & 0.02 & 0.09 & 0.16 & 0.00 \\
\hline Schizomeridaceae** & 5.55 & 1.85 & 2.14 & 0.81 & 0.75 & 0.13 \\
\hline Selenastraceae** & & & & 0.00 & 0.08 & 0.00 \\
\hline Sellaphoraceae** & 0.01 & 0.37 & 0.40 & 0.10 & 1.43 & 0.03 \\
\hline Stauroneidaceae $e^{\star \star}$ & 0.04 & 0.92 & 1.00 & 0.04 & 1.26 & 0.00 \\
\hline Surirellaceae** & 0.05 & 0.65 & 0.70 & 0.09 & 1.43 & 0.02 \\
\hline
\end{tabular}

\begin{tabular}{|c|c|c|c|c|c|c|}
\hline \multirow{2}{*}{ Food items } & \multicolumn{3}{|c|}{ Rainy season } & \multicolumn{3}{|c|}{ Dry season } \\
\hline & Vi\% & $\mathrm{F} i \%$ & IAi & Vi\% & $\mathrm{F} i \%$ & $\mathrm{IA} i$ \\
\hline Ulotrichaceae** & 5.85 & 3.90 & 4.74 & 6.28 & 4.54 & 6.17 \\
\hline Volvocaceae** & 0.05 & 0.18 & 0.30 & & & \\
\hline Zygnemataceae ${ }^{\star *}$ & 5.47 & 2.78 & 2.20 & 8.06 & 9.09 & 8.08 \\
\hline Digested plant material* & 6.68 & 5.47 & 7.60 & 6.75 & 3.87 & 5.65 \\
\hline Macrophytes** & 27.96 & 9.47 & 54.94 & 30.95 & 7.32 & 49.01 \\
\hline \multicolumn{7}{|l|}{ Animal origin } \\
\hline Acari $^{\star}$ & 0.17 & 0.65 & 0.02 & 0.07 & 0.50 & 0.00 \\
\hline Coleoptera* & 4.07 & 3.06 & 2.59 & 1.08 & 2.02 & 0.47 \\
\hline Diptera (adult)** & 0.15 & 0.74 & 0.02 & 0.07 & 0.33 & 0.00 \\
\hline Diptera (larva)* & 0.07 & 0.09 & 0.10 & 0.11 & 0.16 & 0.00 \\
\hline Ephemeroptera* & 0.16 & 0.09 & 0.25 & 0.46 & 0.59 & 0.05 \\
\hline Lepidoptera* & 0.15 & 0.09 & 0.20 & & & \\
\hline Megaloptera* & 0.03 & 0.09 & 0.12 & & & \\
\hline Odonata* & 0.50 & 0.37 & 0.03 & 0.69 & 0.67 & 0.10 \\
\hline Trichoptera* & 2.72 & 1.95 & 1.10 & 0.76 & 1.09 & 0.18 \\
\hline Bosminidae* & & & & 0.01 & 0.08 & 0.00 \\
\hline Ceratopogonidae* & 0.11 & 0.09 & 0.15 & 0.03 & 0.08 & 0.00 \\
\hline Corydalidae* & 0.03 & 0.09 & 0.12 & 0.03 & 0.08 & 0.00 \\
\hline Elmidae* & 0.24 & 0.55 & 0.02 & & & \\
\hline Hydrobiosidae* & & & & 0.03 & 0.08 & 0.00 \\
\hline Lampyridae* & 0.02 & 0.09 & 0.12 & & & \\
\hline Leptophlebiidae* & 0.28 & 0.18 & 0.45 & 0.53 & 0.25 & 0.02 \\
\hline Moinidae* & 0.03 & 0.09 & 0.11 & & & \\
\hline Zooplankton* & 0.01 & 0.09 & 0.32 & 0.02 & 0.16 & 0.00 \\
\hline Cyclopoida* & & & & 0.07 & 0.08 & 0.00 \\
\hline Daphniidae* & 0.14 & 0.83 & 0.98 & 0.08 & 0.58 & 0.00 \\
\hline Fragments of fishes* & & & & 2.02 & 0.50 & 0.22 \\
\hline Scales* & 3.81 & 3.71 & 2.94 & 2.86 & 2.02 & 1.25 \\
\hline Unidentified eggs* & 0.50 & 0.55 & 0.05 & 0.31 & 0.59 & 0.04 \\
\hline Nematoda* & 0.88 & 1.30 & 0.23 & 0.15 & 0.33 & 0.01 \\
\hline $\begin{array}{l}\text { Larvae of unidentified } \\
\text { insects* }\end{array}$ & 2.93 & 3.61 & 1.23 & 0.68 & 1.76 & 0.20 \\
\hline $\begin{array}{l}\text { Allochthonous fragments } \\
\text { of insects**}\end{array}$ & 5.17 & 3.43 & 3.69 & 4.04 & 3.53 & 3.09 \\
\hline $\begin{array}{l}\text { Autochthonous frag- } \\
\text { ments of insects* }\end{array}$ & 0.64 & 0.92 & 0.12 & 1.73 & 0.75 & 0.28 \\
\hline \multicolumn{7}{|l|}{ Unidentified Material } \\
\hline $\begin{array}{l}\text { Material of undetermined } \\
\text { origin }\end{array}$ & 1.07 & 1.30 & 0.29 & 0.46 & 0.08 & 0.50 \\
\hline Detritus/mud** & 1.76 & 5.47 & 2.00 & 2.59 & 5.72 & 3.21 \\
\hline
\end{tabular}


amount of material of plant origin ingested in both the dry season $\left(\chi^{2}=76.7 ; p<0.05 ; \mathrm{df}=1\right)$ and the rainy season $\left(\chi^{2}=\right.$ 56.0; $p<0.05 ; \mathrm{df}=1)$. In both seasons $S$. notomelas ingested mainly items of plant origin.

nMDS analysis indicated that there was considerable overlap of items of animal (stress $=0.11$, where a low stress values indicates a good ordering, ensuring good reliability in the interpretation of the results), plant (stress $=0.08$ ), autochthonous (stress $=0.10$ ) and allochthonous origin (stress $=0.23$ ), consumed by $S$. notomelas in each season, the analysis failed to show any separation on axis 1 and 2 retained for interpretation (Figure 2a-d).
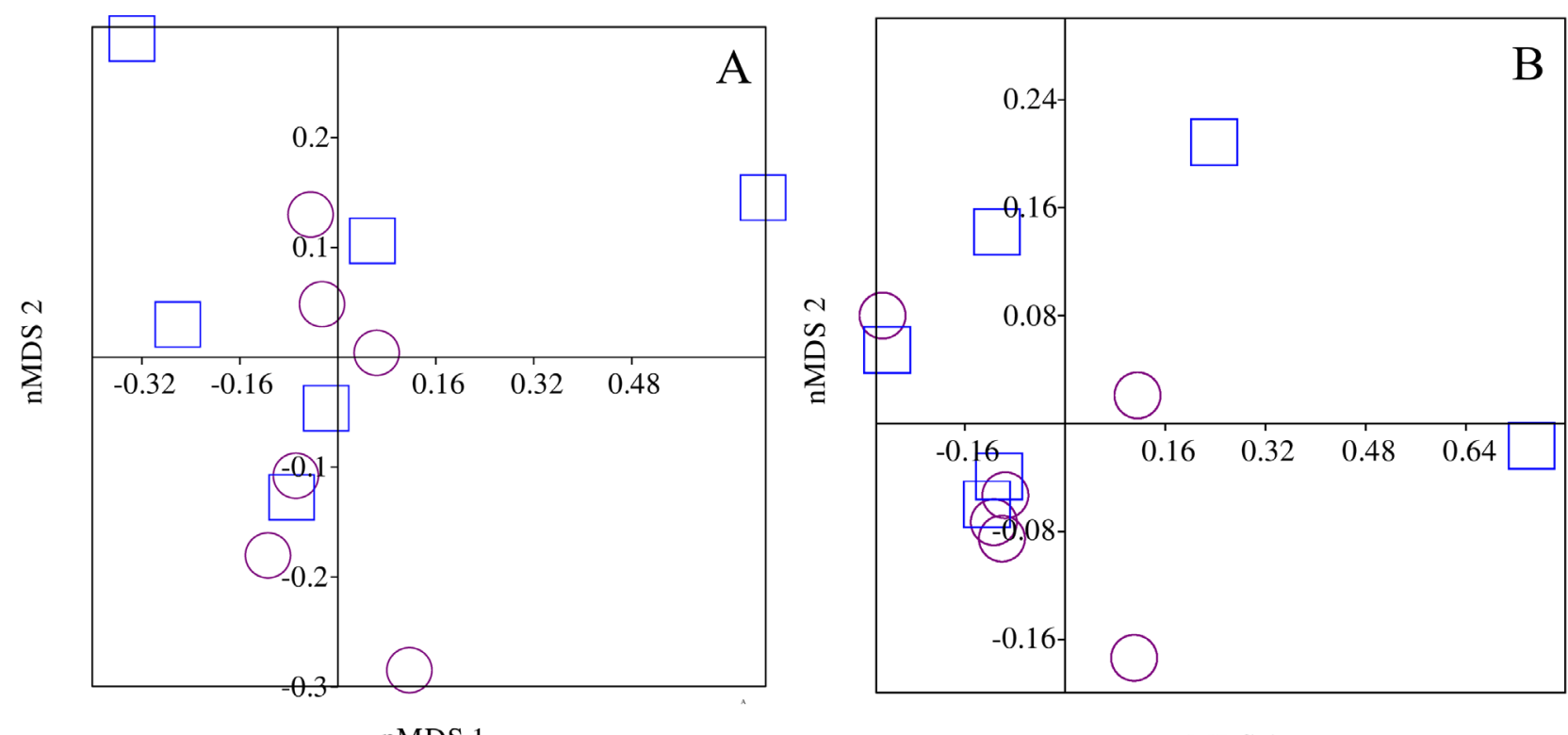

nMDS 1

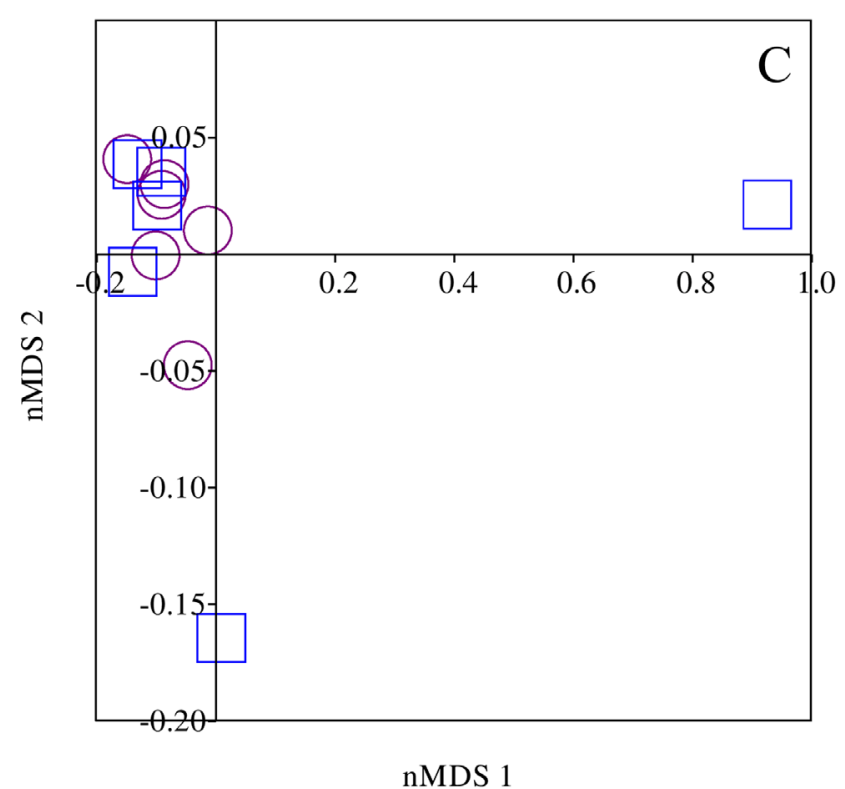

nMDS 1

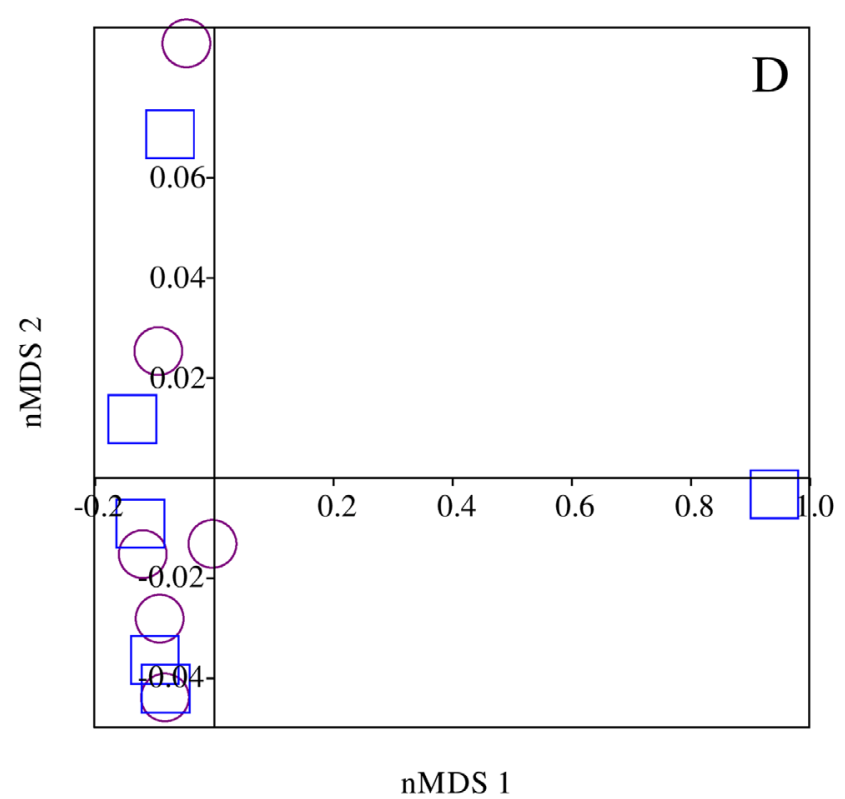

Fig. 2. Non-metric multidimensional scaling analysis of volumetric data for animal (A), plant (B), autochthonous (C) and allochthonous (D) items in the diet of Serrapinnus notomelas during the dry season (square) and rainy season (circle), in streams in the Machado River basin, Brazil, from July 2013 to May 2014. This figure is in color in the electronic version. 


\section{DISCUSSION}

Most of the captured individuals had size between 30 and $32 \mathrm{~mm}$. According to Malabarba (2003), the subfamily Cheirodontinae consists mainly of small individuals that reach a maximum length of $30-40 \mathrm{~mm}$. However, in studies by Lourenço et al. (2008) and Benitez and Súarez (2009), mean length was $26 \mathrm{~mm}$ and $32 \mathrm{~mm}$, respectively. Corroborating the results of our study, Lourenço et al. (2008) reported that LC 23 - $28 \mathrm{~mm}$ had the greatest number of individuals, while for Benitez and Súarez (2009) the corresponding LC was 28 - 32 $\mathrm{mm}$. This result indicates that the species of our study possibly has a body growth (SL) faster than in other locations, which is expected relatively given that it is a foraging species, which should reach the maximum length as soon as possible aiming minimize the chance of predation (Reznick et al. 1996).

The LC distribution for $S$. notomelas was polymodal, a distribution pattern also found in studies of Lundberg and McDade (1986) and Espírito-Santo et al. (2013), which may indicate repeated reproductive episodes throughout the year and, consequently, the presence of various cohorts in the population analyzed in the streams that feed into the Machado river basin. We suggest that predominant absolute frequency of certain size classes in the rainy season is related to the preferred food item of this species. As macrophytes were the most consumed item in the rainy season, the high absolute frequency of the species may be associated with the greater availability of this food resource when the water is deeper.

In studies involving Serrapinnus heterodon in a reservoir in the São Paulo state (Gonçalves et al. 2011) and S. notomelas on a lake in the Paraná River basin (Carniatto et al. 2012), it was found a high frequency of full stomachs, our study corroborate those findings. In fishes, the seasonal cycle of nutritional reserves, such as fat, follows a pattern associated with reproduction (Favero et al. 2010; Freitas et al. 2011; Espírito-Santo et al. 2013), when fishes reduce feeding activity and use the energy stored in fat for gonadal maturation (Santos et al. 2010).

Serrapinnus notomelas shows an opportunistic reproductive strategy, does not exhibit parental care and has continuous reproduction, i.e. multiple clutches (Winemiller 1989). This may explain the large number of individuals with full stomachs in the dry and rainy seasons in our study. Studies carried out in different regions of Brazil have shown that fish reproduction is usually associated with increases in rainfall during the rainy season, when food is more available for offspring (Vazzoler and Menezes 1992; Winemiller 1993; Winemiller et al. 2008). This is in agreement with our findings of more individuals with FI 1 and FI 2 in the rainy season.

Due to the consumption of plant and animal items, we noted that $S$. notomelas is an omnivorous species with tendency to herbivory. Based on tooth morphology, Malabarba (2003) classified Cheirodontinae species mainly as herbivores. This classification was confirmed by the high value of intestinal quotient $(0.62 \mathrm{~mm})$ observed by Gonçalves et al. (2011) for S. heterodon. Hahn and Loureiro-Crippa (2006) and Luiz et al. (1998) studied lagoons and streams in the Paraná river catchment basin and classified $S$. notomelas as an algivorous species, while Minzão et al. (2004) classified it as omnivorous because of its consumption of microcrustaceans and algae. According to Agostinho et al. (2007) omnivorous habits are an important strategy in impacted environments allowing increased energy acquisition according to the availability and quality of food.

In a study on fish/macrophyte interaction in the Rosana reservoir in the state of São Paulo, Brazil, Casatti et al. (2003) reported the algivorous habits of $S$. notomelas. Pelicice and Agostinho (2006) found that this was the only herbivorous species in the same reservoir, feeding almost exclusively on algae and bryophytes. The high consumption of aquatic macrophytes and algae in our study is related to the morphological attributes described for the species. Serrapinnus notomelas has stronger teeth (broader with more cusps), an important feature when scraping periphyton from the stems of submerged macrophytes (Hahn and Loureiro-Crippa 2006). This attribute is important for species that feeds on plant resources, which are known to be difficult to digest. In contrast, carnivorous fishes have shorter intestines (Hahn and Loureiro-Crippa 2006).

It should be noted that the large amount of macrophytes and algae ingested by $S$. notomelas is related to the fact that the submerged parts of macrophytes form a complex habitat made up of stems and roots colonized by algae and invertebrates (Junk 1973) throughout the year. Pelicice et al. (2005) reported that in addition to being used as food source, macrophytes are substratum for periphyton and invertebrates. Associated with this is the fact that the streams studied are in pastures, where there is no plant cover, which can lead to greater periphyton productivity because of the increased light incidence (Mosisch et al. 2001).

The origin of food resources available to fishes may change substantially among streams and rivers. Shaded headwater forest streams contain mainly allochthonous resources and generally harbor fish species that tend to be omnivorous generalists. However, there is some autochthonous primary production in these systems and several fish species take advantage of that. In stream reaches exposed to direct sunlight, some species such as small catfishes (Loricariidae) are the main consumers of periphyton, which they eat as they graze on the surface of submerged tree trunks, macrophytes and rocky substrates (Carvalho et al. 2007).

The diet of $S$. notomelas is dominated by food from autochthonous source. The importance of allochthonous 
material for the feeding of stream fishes is relevant (Nogueira and Costa 2014; Kemenes and Forsberg 2014; Costa and Soares 2015). This shows that $S$. notomelas depends almost exclusively on resources provided by the terrestrial environment. Moreover, Gordon (1993) suggested that allochthonous material may be indirectly important for the diet of fishes because leaves, branches, and tree trunks create microhabitats that support immature forms of insects and other organisms that compose the basis of the autochthonous food resource. In addition, the species is benthopelagic (Malabarba 2003), and its diet indicates a preference for the benthic zone as a foraging site. The preferential use of autochthonous food by stream fishes was also suggested by Casatti (2002) in São Carlos stream, in the state of São Paulo, Brazil, where $70 \%$ of the food ingested by fishes was from autochthonous source.

The fact that many species are restricted to areas with canopy cover has been attributed to input of greater amount of allochthonous material, particularly terrestrial insects (Mazzoni and Iglesias 2002). Thus, the great consumption of autochthonous items by $S$. notomelas may also be related to the reduced vegetation cover in the observed streams.

In this study, $S$. notomelas consumed predominantly material of plant origin. According to Brandáo-Gonçalves et al. (2010), who studied a stream in river Paraná basin, the most abundant and most important items in the $\operatorname{diet}$ of $S$. notomelas were algae and macrophytes. Items of animal origin were not frequent. The species had a strong preference for algae, and its diet did not vary with season. Most likely, because algae are an abundant resource throughout the year, thus there is no need to change the diet to a different food source.

Although different feeding classifications have been used for Cheirodontinae species, the information available in the literature suggests that most of these species have omnivorous habits and that they may consume predominantly, or have a tendency to consume, one particular item (BrandãoGonçalves et al. 2010). Generally, the food items ingested by Cheirodontines are very similar and the food spectrum is relatively limited. Larger items, such as fruits, seeds, fishes and large crustaceans, are never present, and insects of allochthonous origin are rarely found (Souza et al. 2011). Our results contradicts the study by Souza et al. (2011), where fish fragments, scales and allochthonous fragments of insects were found in the guts of $S$. notomelas. This reinforces the idea that this species has omnivorous habits and may consume predominantly one particular item.

Our results suggest that this species has a very similar diet to that of other Cheirodontinae species described in the literature, both in terms of its omnivorous habits and its limited food spectrum. Although the diet of $S$. notomelas included material of animal origin, the species fed essentially on plant items during both seasons. For this reason, it is reasonable to classify the species as omnivorous with tendency to show herbivorous behavior, as observed in other studies (Castro et al. 2004; Dias and Fialho 2009; Brandão-Gonçalves et al. 2010).

\section{CONCLUSION}

Serrapinnus notomelas species shows a polymodal distribution pattern of LC, being one indicative that repeated reproductive episodes throughout the year and, consequently, the presence of various cohorts in the population analyzed. The absolute frequency of some size classes in the rainy season is related to the preferred food (macrophytes) item of this species. Serrapinnus notomelas has omnivorous feeding habits. Autochthonous plant material constitutes a large part of its diet, possibly because autochthonous items are of greater importance in fish diets. There was no evidence of seasonal changes in the fullness index and diet of $S$. notomelas apart from a reduction in the frequency of consumption of some items. However we noted significant differences between the amount of food items of allochthonous origin and autochthonous origin ingested in the dry and rainy seasons. Also, that was observed for the items of animal and plant origin. This is most likely because of the constant availability of food and the broad spectrum of food consumed by this species.

\section{ACKNOWLEDGEMENTS}

We are grateful to PIBIC/UNIR for providing an undergraduate research project scholarship for VMR. We would like to thank the staff at the Laboratório de Ictiologia e Pesca da Universidade Federal de Rondônia, particularly Marina Fonseca for helping us with the identification of stomach contents and Carolina Doria for allowing us to use the facilities.

\section{REFERENCES}

Abelha, M.C.F.; Agostinho, A. A.; Goulart, E. 2001. Plasticidade trófica em peixes de água doce. Acta Scientarium, 23: 425-434.

Abilhoa, V.; Bormaatowski, H.; Otto, G. 2009. Temporal and ontogenetic variations on feeding habits of Hollandichthys multifasciatus (Teleostei: Characidae) in coastal Atlantic rainforest streams, southern Brazil. Neotropical Ichthyology, 7: 415-420.

Agostinho, A. A.; Gomes, L. C.; Pelicice, F. M. (Eds.). 2007. Ecologia e Manejo de Recursos Pesqueiros em Reservatórios do Brasil. Maringá, Eduem, 501p.

Angermeier, P. L.; Karr, J. R. 1983. Fish communities along environmental gradients in a system of tropical streams. Envirommental Biology Fishes, 9: 117-135.

Benitez, R. S.; Súarez, Y. R. 2009. Biologia populacional de Serrapinnus notomelas (Eingenmann, 1915) (Characiformes, Cheirodontinae) em um riacho de primeira ordem na bacia do rio Dourados, Alto rio Paraná. Pan-American Journal of Aquatic Sciences, 4: 271-278. 
Bicudo, C. E. M.; Bicudo, R. M. T. (Eds.). 1970. Algas de águas continentais brasileira: chave ilustrada para identificação de gêneros. São Paulo, Fundaçáo Brasileira para o desenvolvimento do Ensino de Ciências, 228p.

Brandão-Gonçalves, L.; Oliveira, S. A.; Lima-Junior, S. E. 2010. Hábitos alimentares da ictiofauna do córrego Franco, Mato Grosso do Sul, Brasil. Biota Neotropica, 10: 21-30.

Bührnheim, C. M.; Carvalho, T. P.; Malabarba, L. R.; Weitzman, S. H. 2008. A new genus and species of characid fish from the Amazon basin: the recognition of a relictual lineage of characid fishes (Ostariophysi: Cheirodontinae: Cheirodontini). Neotropical Ichthyology, 6: 663-678.

Carniatto, N.; Fugi, R.; Cantanhêde, G.; Gubiani, É. A.; Hahn, N. S. 2012. Effects of flooding regime and diel cycle on diet of a small sized fish associated to macrophytes. Acta Limnologica Brasiliensia, 24: 363-372.

Carvalho, L. N.; Zuanon, J.; Sazima, I. 2007. Natural History of Amazon Fishes. In: Del Claro, K., P.S. Oliveira, V. Rico-Gray, A. Ramirez, A. A. A. Barbosa, A. Bonet (Ed.). Natural history of Amazon fishes. Tropical Biology and Conservation Management: Case studies. v. 1. Eolss Publishers, Oxford, p. 113-144.

Carvalho, M.S.; Zuanon. J.; Ferreira, E. J. G. 2013. Diving in the sand: the natural history of Pygidianops amphioxus (Siluriformes: Trichomycteridae), a miniature catfish of Central Amazonian streams in Brazil. Environmental Biology of Fishes, 97: 59-68.

Casatti, L. 2002. Alimentação dos peixes em um riacho do parque estadual Morro do Diabo, bacia do alto rio Paraná, sudeste do Brasil. Biota Neotropica, 2: 1-14.

Casatti, L.; Mendes, H. F.; Ferreira, K. M. 2003. Aquatic macrophytes as feeding site for small fishes in the Rosana Reservoir, Paranapanema River, Southeastern Brazil. Brazilian Journal of Biology, 63: 213-222.

Castro, R. M.; Casatti, L.; Santos, H. F.; Melo, A. L.; Martins, L. S.; Ferreira, K. M.; Langeani, F. 2004. Estrutura e composição da ictiofauna de riachos da bacia do rio Grande no estado de São Paulo, sudeste do Brasil. Biota Neotropica, 4: 1-39.

Clarke, K. R.; Warwick, R. M. 1994. Similarity-based testing for community pattern: the two-way layout with no replication. Marine Biology, 118: 167-176.

Corrêa, J. M.; Gerhard, P.; Figueiredo, R. O. 2012. Ictiofauna de igarapés de pequenas bacias de drenagem em área agrícola do Nordeste Paraense, Amazônia Oriental. Revista Ambiente \& Água-An Interdisciplinary Journal of Applied Science, 7: 214-230.

Costa, I. D.; Soares, M. O. 2015. The seasonal diet of Aequidens tetramerus (Cichlidae) in a small forest stream in the Machado River basin, Rondônia, Brazil. Acta Amazonica, 45: 365-372.

Dias, T. S.; Fialho, C. B. 2009. Biologia alimentar de quatro espécies simpátricas de Cheirodontinae (Characiformes, Characidae) do rio Ceará Mirim, Rio Grande do Norte. Iheringia, Série Zoologia, 99: 242-248.

Espírito-Santo, H. M. V.; Magnusson W. E.; Zuanon, J.; Mendonça, F. P.; Landeiro, V. L. 2009. Seasonal variation in the composition of fish assemblages in small Amazonian forest streams: evidence for predictable changes. Freshwater Biology, 54: 536-548.

Espírito-Santo, H.M.V.; Rodríguez, M.A.; Zuanon, J. 2013. Reproductive strategies of Amazonian stream fishes and their fine-scale use of habitat are ordered along a hydrological gradient. Freshwater Biology, 58: 2494-2504.
Esteves, K. E.; Aranha, J. M. R. 1999. Ecologia Trófica de peixes de riachos. In: Caramaschi, E. P.; Mazzoni, R.; Peres Neto, P. R. (Ed.). Ecologia de Peixes de Riachos. v.1. Universidade Federal do Rio de Janeiro, Rio de Janeiro, Rio de Janeiro, p. 157-182.

Fernandes, L.C.; Guimarães, S.C.P. (Eds.). 2002. Atlas geoambiental de Rondônia. PortoVelho, SEDAM, 96p.

Favero, J.M.; Pompeu, P.S.; PradoValladares, A.C. 2010. Biologia reprodutiva de Heros efasciatus Heckel, 1840 (Pisces, Cichlidae) na Reserva de Desenvolvimento Sustentável Amanã - AM, visando seu manejo sustentável. Acta Amazonica, 40: 373-380.

Ferreira, F. S.; Vicentin, W.; Costa, F. E. S.; Súarez, Y. R. 2014. Trophic ecology of two piranha species, Pygocentrus nattereri and Serrasalmus marginatus (Characiformes, Characidae), in the floodplain of the Negro River, Pantanal. Acta Limnologica Brasiliensia, 26: 381-391.

Freitas, T. M. D. S.; Almeida, V. H. D. C.; Montag, L. F. D. A.; Rocha, R. M. D.; Fontoura, N. F. 2011. Seasonal changes in the gonadossomatic index, allometric condition factor and sex ratio of an auchenipterid catfish from eastern Amazonia. Neotropical Ichthyology, 9: 839-847.

Gonçalves, C. D. S.; Souza, U. P.; Braga, F. M. D. S. 2011. Population structure, feeding and reproductive aspects of Serrapinnus heterodon (Characidae, Cheirodontinae) in a Mogi Guaçu reservoir (SP), upper Paraná River basin. Acta Limnologica Brasiliensia, 23: 13-22.

Gordon, N. D. 1993. Stream hydrology: an introduction. Chichester, John Wiley and Sons, 448p.

Hahn, N.S.; Loureiro, V.E.; Delariva, R.L. 1999. Atividade alimentar de curvina Plagioscion squamosissimus (Heckel, 1840) (Perciformes, Sciaenidae) no rio Paraná. Acta Scientiarum, 21: 309-314.

Hahn, N. S.; Loureiro-Crippa, V. E. 2006. Estudo comparativo da dieta, hábitos alimentares e morfologia trófica de duas espécies simpátricas, de peixes de pequeno porte, associados à macrófitas aquáticas. Acta Scientiarum. Biological Sciences, 28: 359-363.

Hamada, N.; Ferreira-Keppler, R. L. 2012. Guia ilustrado de insetos aquáticos e semiaquáticos da Reserva Florestal Ducke. Manaus, Universidade Federal do Amazonas, 198p.

Hamada, N.; Nessimian, J. L.; Querino, R. B. 2014. Insetos aquáticos na Amazônia brasileira: taxonomia, biologia e ecologia. Manaus, Embrapa Meio Norte Livros Científicos, 724p.

Hammer, O.; Harper, D. A. T.; Ryan, P. D. 2001. PAST: Paleontological Statistics Software Package for Education and Data Analysis. Palaeontologia Electronica, 4: 1-9.

Hellawell, J. M.; Abel, R. 1971. A rapid volumetric method for the analysis of the food of fishes. Journal Fish Biology, 3: 29-37.

Hyslop, E. J. 1980. Stomach contents analysis: a review of methods and their application. Journal Fish Biology, 100: 411- 429.

IBAMA, 2008. Diagnóstico geral das práticas de controle ligadas a exploração, captura, comercialização, exportação e uso de peixes para fins ornamentais e de aquariofilia, 1:1-5(http://www. ibama.gov.br/phocadownload/recursos_pesqueiros/diagnostico_ completo.pdf). Accessed on 03/07/2016.

Junk, W. J. 1973. Investigations on the ecology and productionbiology of the "floating meadows" (Paspalo-Echinochloetum) on the middle Amazon. The aquatic fauna in the root-zone of floating vegetation. Amazoniana, 4: 9-102. 
Kawakami, E.; Vazzoler, G. 1980. Método gráfico e estimativa de índice alimentar aplicado no estudo de alimentação de peixes. Boletim do Instituto Oceanográfico, 29: 205-207.

Kemenes, A.; Forsberg, B. R. 2014. Factors influencing the structure and spatial distribution of fishes in the headwater streams of the Jaú River in the Brazilian Amazon. Brazilian Journal of Biology, 74: 23-32.

Krusche, A.V.; Ballester, M. V. R.; Bernardes, M. C.; Leite, N. K. J.; Hanada, L.; Victoria, D. C.; et al. 2005. Efeitos das mudanças do uso da terra na biogeoquímica dos corpos d'água da bacia do rio Ji-Paraná, Rondônia. Acta Amazonica, 35: 197-205.

Lévêque, C.; Oberdorff, T.; Paugy, D.; Stiassny, M. L. J.; Tedesco, P. 2008. Global diversity of fish (Pisces) in freshwater. Hidrobiologia, 595: 545-567.

Lourenço, L. D. S.; Súarez, Y. R.; Florentino, A. C. 2008. Populational aspects of Serrapinnus notomelas (Eigenmann, 1915) e Bryconamericus stramineus Eigenmann, 1908 (Characiformes: Characidae) in streams of Ivinhema River Basin, Upper Paraná Basin. Biota Neotropica, 8: 0-0.

Luiz, E. A.; Agostinho, A. A.; Gomes. L. C.; Hahn, N. S. 1998. Ecologia trófica de peixes em dois riachos da bacia do rio Paraná. Revista Brasileira de Biologia, 58: 273-285.

Lundberg, J. G.; McDade, L. A. 1986. On the South American catfish Brachyrhamdia imitator Myers (Siluriformes, Pimelodidae), with phylogenetic evidence for a large intrafamilial lineage. Notulae Naturae, 463:1-24.

Malabarba, L. R. 2003. Subfamily Cheirodontinae. In: Reis, R.; Kullander, S.; Ferraris, C. E. D. S. (Ed.). Check list of the freshwater fishes of South and Central America. v. 1. Edipucrs, Porto Alegre, Rio Grande do Sul, p. 215-221.

Mazzoni, R.; Iglesias, R. R. 2002. Distribution pattern of two fish species in a coastal stream in the southeast of Brazil. Brazilian Journal Biology, 62: 171-178.

Mendonça, F. P., W. E. Magnusson; Zuanon, J. 2005. Relationships between habitat characteristics and fish assemblages in small streams of Central Amazonia. Copeia, 4: 751-764.

Mendonça, F.; Pazin, V.; Espírito-Santo, H.; Zuanon, J.; Magnusson, W. E. 2008. Peixes. Pp. 63-76. In: Oliveira, L. M.; Bacaro, F. B.; Braga-Neto, R.; Magnusson, W. E. (Ed.). Reserva Ducke: A biodiversidade amazônica através de uma grade. v.1. Áttema Design Editorial, Manaus, Amazonas, p.63-76.

Minzão, L. D.; Brucznitsk, V. F. B.; Cardoso. L. Q. F. 2004. Sazonalidade na dieta de duas espécies de peixes do gênero Serrapinnus, em uma lagoa marginal do alto Rio Paraná. Brasília, Editora UNB, 306p.

Mosisch, T. D.; Bunn. S. E.; Davies, P. M. 2001. The relative importance of shading and nutrients on algal production in subtropical streams. Freshwater Biology, 46: 1269-1278.

Nogueira, W. V.; Costa, I. D. 2014. Aspectos da alimentação de Knodus heteresthes (Characiformes, Characidae) no igarapé do Nove, bacia do rio Machado, Rondônia, Brasil. Biotemas, 27: 1-9.

Pelicice, F. M.; Agostinho, A. A. 2006. Feeding ecology of fishes associated with Egeria spp. patches in a tropical reservoir, Brazil. Ecology of Freshwater Fish, 15: 10-19.

Pelicice, F. M.; Agostinho, A. A.; Thomaz, S. M. 2005. Fish assemblages associated with Egeria in a tropical reservoir: investigating the effects of plant biomass and diel period. Acta Oecologica, 27: 9-16.
Petts, G. E. 1994. Rivers: Dynamic components of catchments ecosystem. In: Calow, P.; Petts, G. E. (Ed.). The River Handbook: The science and management of rivers environments. v.1. Oxford, Blackwell Scientific, p. 3-22.

Queiroz, L. J.; Torrente-Vilara, G.; Ohara, W. M.; Pires, T. H. S.; Zuanon, J.; Doria, C. R. C. (Eds.). 2013. Peixes do rio Madeira. São Paulo, Dialeto Latin American Documentary, 467p.

Reis, R.; Kullander, S.; Ferraris, C. E. D. S. (Eds.). 2003. Check List of the Freshwater Fishes of South and Central America. Porto Alegre, EDIPUCRS, 729p.

Reznick, D. N.; Butler, I.V.M. J.; Rodd, F. H.; Ross, P. 1996. Lifehistory evolution in guppies (Poecilia reticulata). Differential mortality as a mechanism for natural selection. Evolution, 50: $1651-1660$.

Santi-Rampazzo, A. P.; Nishiyama, P. B.; Ferreira, P. E. B.; Martins-Santos, I. C. 2008. Intrapopulational polymorphism of nucleolus organizer regions in Serrapinnus notomelas (Characidae, Cheirodontinae) from the Parana River. Journal of fish Biology, 72: 1236-1243.

Santos, R.; Amadio, S.; Ferreira, E.J.G. 2010. Patterns of energy allocation to reproduction in three Amazonian fish species. Neotropical Ichthyology, 8: 155-162.

Souza, W.D.; Silva, S.A.A; Bilce, J.M. 2011. Dieta natural de Serrapinnus kriegi (Schindler, 1937) (Characidae: Cheirodontinae) no córrego ribeirão, alto tapajós, Brasil. Revista de Ciências AgroAmbientais, 9: 97-108.

Sturges H. A. 1926. The choice of a class interval. Journal of the American Statistical Association, 21:65-66.

Suzuki, H. I.; Vazzoler, A. E. A. M.; Marques, E. E.; Lizama, M. P.; Inada. P. 2004. Reproductive ecology of fish assemblages. In: Thomaz, S. M. A. A.; Agostinho, A. A.; Hahn, N. S. (Ed.). The upper Parana river floodplain: physical aspects, ecology and conservation. v. 1. Backhuys publishers, Leiden, p. 271-291.

Vazzoler, A. E. A. M.; Menezes, N. A. 1992. Síntese de conhecimentos sobre o comportamento reprodutivo dos Characiformes da América do Sul (Teleostei, Ostariophysi). Revista Brasileira de Biologia, 52: 627-640.

Winemiller, K. O. 1989. Patterns of variation in life history among South American fishes in seasonal environments. Oecologia, 81: 225-241.

Winemiller, K. O. 1993. Seasonality of reproduction by liver bearing fishes in tropical rainforest streams. Oecologia, 95: 266-276.

Winemiller, K.O.; Agostinho, A.A.; Caramaschi, E.P. 2008. Fish ecology in tropical streams. Tropical stream ecology, 1: 107-146.

Ximenes, L. Q. L.; Mateus. L. A. F.; Penha. J. N. F. 2011. Variação temporal e espacial na composição de guildas alimentares da ictiofauna em lagoas marginais do Rio Cuiabá, Pantanal Norte. Biota Neotropica, 11: 205-215.

Zar, J. H. 1999. Biostatistical analysis. New Jersey, Prentice Hall, $663 \mathrm{p}$.

Received: 08/07/2016

Accepted: 12/09/2016 